\title{
ヨードカリ溶液中におけるインジウムのポーラログラフ的挙動
}

\section{Polarographic Behaviours of Indium in Potassium Iodide Solutions}

\author{
松 前 鼎 \\ Teiichi Matsumae
}

\section{1. 緒言}

インジウムのポーラログラフ的な研究はかなり崫くか ら行わ机ているが(1)(2), 主として物理化学的な胃地から の考察が多い，すなわち Lingane(3)性可逆系ポーラログ ラフ波の解析炕あたって3価還元の例としてインジウム をとりまげ, Schufle, Stubbs, Witmann ${ }^{(4)}$ は $1 \times 10^{-3}$ $\mathrm{mol} / l$ の $\mathrm{InCl}_{3}$ の塩酸酸性溶液飞ついての半波電位を娜

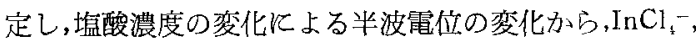
$\mathrm{InCl}_{2}{ }^{+}$のクロロ錯イオンの存在することを報告して抒 り, Cozzi, Vivarel1(5) は $0.1 \mathrm{M}$ の $\mathrm{HClO}_{4}$ 帆机打る $5.27 \times 10^{-4} \mathrm{~mol} / l$ のインジゥム溶液に, 各種濃度の八ロ ゲンイオンを添加して，そのときの半波電位の変化から $\operatorname{In}\left(\mathrm{H}_{2} \mathrm{O}\right)_{5} \mathrm{X}_{1}{ }^{2+}, \operatorname{In}\left(\mathrm{H}_{2} \mathrm{O}\right)_{4} \mathrm{X}_{2}{ }^{+}$なる二つの水和ハロゲン錯 イオンが存在することを提喟している。香た Nakatani ${ }^{(6)}$

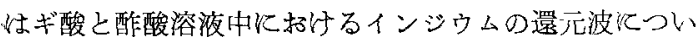
て報告している。

最近インジウムは高速度回転軸の軸受のメッキ材料や トランジスターなどの材料として注目されている．元来 インジゥムは主として閭亜鉛鉱中の微量成分として産出 するのであるが，わが国格いては重鈶精煉の副座物で あるブルーパウダーやカドミウム回収経䀩の鉄沈殿など がインジウムの主原料として有望視され，卆和らの品位 決定のために適当から簡便な分析法の確立が望李れてい る.

これらの副産物中ではインジウムは常に多量のカドミ ウム，鉄，亚鈆などと共存しているため，化学分析法沉 上って定量する場合，かなり㥧雑な分離操作を綝返さな けれ聇正確な定量値を期待するととはできない。

Kolthoff，Lingane の無機物半波電位表 ${ }^{(7)}$ 飞上れば， 塭化カリ，ヨードカりを支持電解質としたときのインジ ウムの半波電位はそれぞれ第 1 表に示すと括りで京る。 この表からわかるように塩化カリ溶液中ではインジム とカドミウムの半波電位の差は約 $30 \sim 50 \mathrm{mV}$ でもり， 峏者の還元波は重なり合って、インジムム分離定量す ることは不可能である。しかしヨードカり溶液中では，

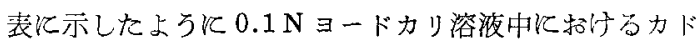

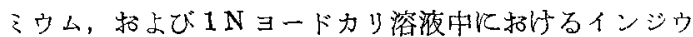
么の半波電位の測定值がないが，両者の半波電位の間侣

* インジウムの定量分析的研究(第 4 報)Quantitative Determination of Indium (Part 4)

**名古屋工業技術試験峃 昭和 29 年 4 月 日本化学会第 7 年会て講活
かなりの差異があるようであり，分離波を得る可能性が 㫽められる。

第 1 表 $\mathrm{In}, \mathrm{Cd}$ の半波電位

\begin{tabular}{l|c|c}
\hline \multirow{2}{*}{ 支持電解算 } & 半泣電位 (V) (vs. S.C.E) \\
\cline { 2 - 3 } & In & $\mathrm{Cd}$ \\
\hline $0.1 \mathrm{~N} \mathrm{KCl}$ & -0.56 & -0.59 \\
$1.0 \mathrm{~N} \mathrm{KC1}$ & -0.59 & -0.64 \\
$0.1 \mathrm{~N} \mathrm{KI}$ & -0.53 & -0.74 \\
$1.0 \mathrm{~N} \mathrm{KI}$ & & \\
\hline
\end{tabular}

著者はこの点に着目して，0.1 1.5 N のヨードカリ 溶液を基礎液として各種浱度のインジウム，カドミウム の半波電位，限界電流を測定するとともに，ゼラチン添 加量の影響を検討し、インジウムとカドミウムのポーラ ログラフ湖同時定量法江対与る定性的定量的基盤を明ら かにした.

\section{2. 実験装置亡試薬}

ポーラログラフ装置 柳本製作所製写寘記録式ポー ラロダラフおよび PB 3 型自動ペン記録式ポーラログラ つを使用した．電解ビンは型電解ビンを解い飽和カ口 メル電極を刘極とした．実験はすべて $25^{\circ} \doteq 0.1^{\circ} \mathrm{C}$ の恒 温りょ中で行なった。

$0.05 \mathrm{M} \mathrm{InCl}_{3}$ 溶液 純金属インジウム (New Metals and Chemicals Corporation, England) (純度 99.9\%) $2.869 \mathrm{~g}$ を(1:1) 塩酸約 $10 \mathrm{~m} l$ 溶解し，水浴上で伍 とんど蒸発乾固し，少量の境酸と蒸留水に溶解する. $500 \mathrm{~m} l$ のメスフラスコに移し蒸留水で正磪に標線まで ろすかる。

$0.05 \mathrm{M} \mathrm{CdSO}_{4}$ 溶液方販特級硫酸カドミウムの飽 和水溶液にエチルアルコールを加完，3回再結晶精製し たるのを用い $0.05 \mathrm{M} \mathrm{CdSO}_{4}$ 溶液を調製した。

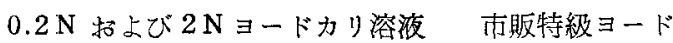
カりを用いて $0.2 \mathrm{~N}$ 抢よび $2 \mathrm{~N}$ の溶液を調製した。こ のヨードカリ溶液は $\mathrm{IO}_{3}$-の存否を榆し，もし存在する ときはあらかじめ除去して和く必要がある。先の他実験 に供した武萝市市販特級品を使用した。

\section{3. 実験方法亡結果}

\section{1 インジウムの半波電位}

上記標準溶液、ヨードカリ溶液括よび $0.1 \%$ ゼうキン 溶液の一定量を $50 \mathrm{~m} l$ のメスフラスコにとり，水で標線 
まで正確にうする試料溶液とする。1 $\mathrm{N}, 0.1 \mathrm{~N} \equiv$-ドカ り溶液中に拾ける各種濃度のインジウム括よび $0.1 〜 1.5$

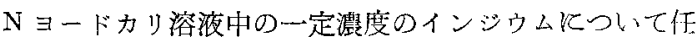
意加電圧拡大装置 ${ }^{(8)}$ 在用い，ポテンシオメータージラム の雨端電玨を $0.5 \mathrm{~V}$ としてインジムの還元波を㠹心 にして拡大したポーラログシムを記録した，還元波の前 後の定常部に扔ける三点の笔位杂電位差計により読取 り，残余電流を補正した電流值 $i$ と，溶液抵抗による電 王降下 $i R$ を補正した電位 $E$ から效数プロット(9)によ り $E_{1 / 2}$ 求めた. その結果を第 2 表に示す.

第 2 表 インジウムの半波笔任

\begin{tabular}{|c|c|c|c|}
\hline & $\begin{array}{c}\text { In } \sigma \text { 潧度 } \\
\left(\times 10^{-3} \mathrm{~mol} / l\right)\end{array}$ & $\begin{array}{c}\mathbf{K I} \text { 港度 } \\
(\mathrm{N})\end{array}$ & $\begin{array}{l}\text { In } 0 \text { 平波電位 } \\
\text { (V) (vs. S.C.E.) }\end{array}$ \\
\hline 1 & 1.6 & 0.1 & $-0.53_{7}$ \\
\hline 2 & 1.0 & $"$ & $-0.53_{8}$ \\
\hline 3 & 0.4 & $\Rightarrow$ & $-0.53_{7}$ \\
\hline 4 & 0.2 & $\Rightarrow$ & $-0.53_{8}$ \\
\hline 5 & 1.0 & 0.2 & $-0.54_{4}$ \\
\hline 6 & $"$ & 0.3 & $-0.54_{3}$ \\
\hline 7 & $"$ & 0.4 & $-0.55_{2}$ \\
\hline 8 & " & 0.5 & $-0.5 .5_{3}$ \\
\hline 9 & " & 0.6 & $-0.5 . \tilde{z}_{6}$ \\
\hline 10 & $"$ & 0.7 & $-0.5 \bar{s}_{6}$ \\
\hline 11 & $"$ & 0.8 & $-0.5 \hat{s}_{1}$ \\
\hline 12 & $"$ & 1.0 & $-0.5 \delta_{z}$ \\
\hline 13 & 1.6 & " & $-0.56_{2}$ \\
\hline 14 & 1.0 & $"$ & $-0.56_{1}$ \\
\hline 15 & 0.4 & " & $-0.56_{1}$ \\
\hline 16 & 0.2 & 1.5 & $-0.56_{7}$ \\
\hline
\end{tabular}

\section{2 カドミウムの半波電位}

$1 \mathrm{~N}, 0.1 \mathrm{~N}$ のヨードカリ溶液中に拈ける各種婊度の力 ドミウムについて，インジムの場合と同様にしてポー ラログラムを記録してカドミウムの半波電位在決定し た. その結果を第 3 表に示す.

第 3 表 カドミウムの半波電位

\begin{tabular}{|c|c|c|c|}
\hline & $\begin{array}{c}\text { Cdの濃度 } \\
\left(\times 10^{-3} \text { mol } l\right)\end{array}$ & 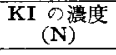 & $\begin{array}{l}\text { Cd 9半波電位 } \\
\text { (V) (vs.S.C.E.) }\end{array}$ \\
\hline 1 & 1.6 & 0.1 & -0.621 \\
\hline 2 & 1.0 & $"$ & -0.620 \\
\hline 3 & 0.4 & $"$ & -0.620 \\
\hline 4 & 0.2 & $"$ & -0.621 \\
\hline 5 & 1.6 & 1.0 & -0.741 \\
\hline 6 & 1.0 & * & -0.741 \\
\hline 7 & 0.4 & $"$ & -0.741 \\
\hline 8 & 0.2 & $\Rightarrow$ & -0.743 \\
\hline
\end{tabular}

\section{3 水銀柱の高さとインジウムの限界電流との関係}

つぎにインジウムの限界電流の性質を検討寸るため に, 水銀柱の高さを $51.0,55.0,59.0,64.0 \mathrm{~cm}$ と変化 させて各点に剧けるインジムの限界䉓流を $0.1 ， 1 \mathrm{~N}$ ヨードカリ溶液を基礎液として測定した，その結果を第 4 表に示したが，インジウのの限界熋流は水鑹柱の高さ の平方根に比例していることがわかる。

この結果と第 5 䒾に示句ように 15，20，25，30 扎上 び $40^{\circ} \mathrm{C}$ に颃いて測定した限界電流の值から計算した温 度係数が， $1 \mathrm{~N}$ ヨードカリ溶液に顿いては $1.37 \%, 0.1 \mathrm{~N}$
第 4 表 水銀柱の高さと限界殗流との関係

In $1 \times 10^{-3} \mathrm{~mol} / l$, ゼラチン $0.015 \%$

\begin{tabular}{|c|c|c|c|c|}
\hline 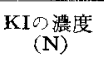 & ${ }_{(\mathrm{cm})}{ }^{\mathrm{a}}$ & $\begin{array}{c}\text { 限界電流 } \\
(\mu \mathrm{A})\end{array}$ & $\begin{array}{c}\text { 高さの平方根 } \\
\left(\nu h_{\text {cor } r}\right)\end{array}$ & $i_{l} / v \overline{h_{C O U} r}$ \\
\hline 1.0 & 51.0 & 5.83 & 6.99 & 0.845 \\
\hline$"$ & 55.2 & 6.04 & 7.29 & 0.829 \\
\hline " & 59.0 & 6.26 & 7.55 & 0.829 \\
\hline$"$ & 64.0 & 6.52 & 7.87 & 0.828 \\
\hline 0.1 & 51.0 & 5.74 & 6.99 & 0.821 \\
\hline$"$ & 55.2 & 5.96 & 7.29 & 0.818 \\
\hline " & 59.0 & 6.19 & 7.55 & 0.820 \\
\hline$"$ & 64.0 & 6.44 & 7.87 & 0.818 \\
\hline
\end{tabular}

ヨードカリ溶液に呿いては $1.39 \%$ でむることから、1 ンジウムの限界電流は掋散律速によるものと考克られ る.

第 5 表 限界電流飞対する温度の影婆

In $1 \times 10^{-3} \mathrm{~mol} / l$, ゼラチン $0.015 \%$

\begin{tabular}{|c|c|c|c|c|c|c|}
\hline \multirow{2}{*}{$\begin{array}{c}\mathrm{KI} \text { 涇度 } \\
(\mathrm{N})\end{array}$} & \multicolumn{5}{|c|}{ 限 界 電 流 $(\mu \mathrm{A})$} & \multirow{2}{*}{ 温度係数 } \\
\hline & $15^{\circ} \mathrm{C}$ & $20^{\circ} \mathrm{C}$ & $25^{\circ} \mathrm{C}$ & $30^{\circ} \mathrm{C}$ & $40^{\circ} \mathrm{C}$ & \\
\hline 1.0 & 5.37 & 5.70 & 6.22 & 6.60 & 7.49 & \multirow{2}{*}{$1.37 \%$} \\
\hline$*$ & 5.42 & 5.70 & 6.20 & 6.69 & 7.51 & \\
\hline 0.1 & 5.09 & 5.58 & 6.11 & 6.46 & 7.45 & \multirow{2}{*}{$1.39 \%$} \\
\hline 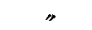 & 5.16 & 5.61 & 6.13 & 6.48 & 7.40 & \\
\hline
\end{tabular}

\section{4 インジウムの濃度と拡散電流との関保}

$1 \mathrm{~N}$ のヨードカリ溶液中に㕲けるインジウムの濃度と 拡散笔流の関係走榆討し $0.2 \times 10^{-3} \mathrm{~mol} / l$ 少ら $5 \times 10^{-3}$ $\mathrm{mol} / l$ の範囲で，インジウムの拡散電流《その濃度に非 労に上く比例することを認めた。その結果を搪散電流測 定の再現性の検討の結果とともに第 5 報において詳しく 述べることにする。

\section{5 ゼラチンの影響}

垻化カり, 塩酸, 過塩素酸カリなど各種の支持電解質 |に稀けるインジウムの還元波は非常に興味ある挙動を 亦し，ゼラチン,メチルレッドなどの極大抑制剤の影響 もかなり複雑であることが報告されている(4).

著者は $5 \times 10^{-4} \mathrm{~mol} / l$ インジウム溶液に $0.1 \%$ ゼラチ ン湥液を小量ずつ添加して，ゼラチンの添加量の変化化 ミるインジウム還元波の挙動を検討した。

$1 \mathrm{~N}$ ヨードカリ溶液を基礎滩とした場合（第 1 図）は ゼう沃ンの添加量が $0.002 \%$ 以下では陽性極大を示し (曲線 $1 \sim 3$ ), $0.004 \%$ 以上では極太が消隇し典型的な 僈元波が得られる．極大波の大きさはゼラチンの添加量 が増加するにしたがって濑減する㑯向炕あるが，その間 飞比例関䋆が成立するとは認められない。

$0.1 \mathrm{~N}$ ヨードカリ溶液を基礎液とした場合（第 2 図） に颃いては，ゼラチンの添加晴が $0.001 \%$ 以下では陽性 極大素示し（曲線6～7）0.002\% 以上では極大波が消， 滅し热型们な還元波が得られる。しかしゼラチンの添加 特が $0.02 \%$ 程度になると還元波の傾斜は中るやかにな 


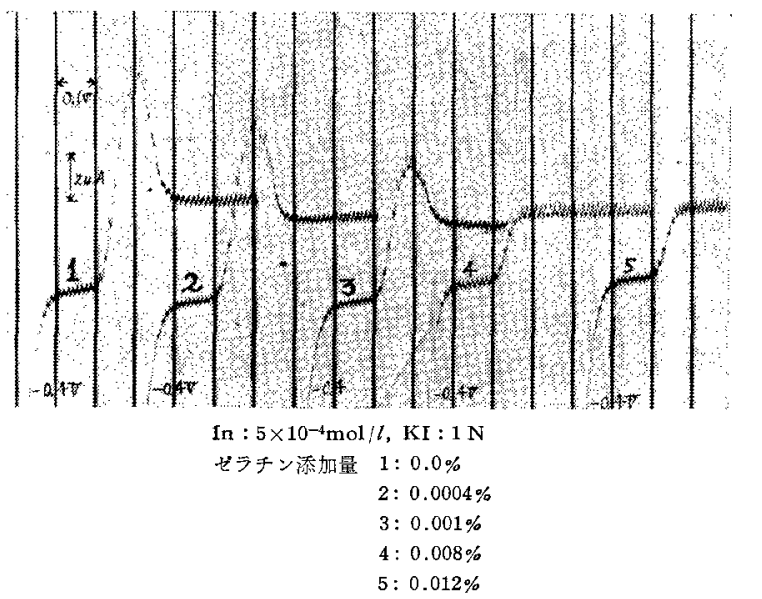

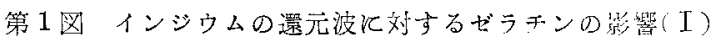

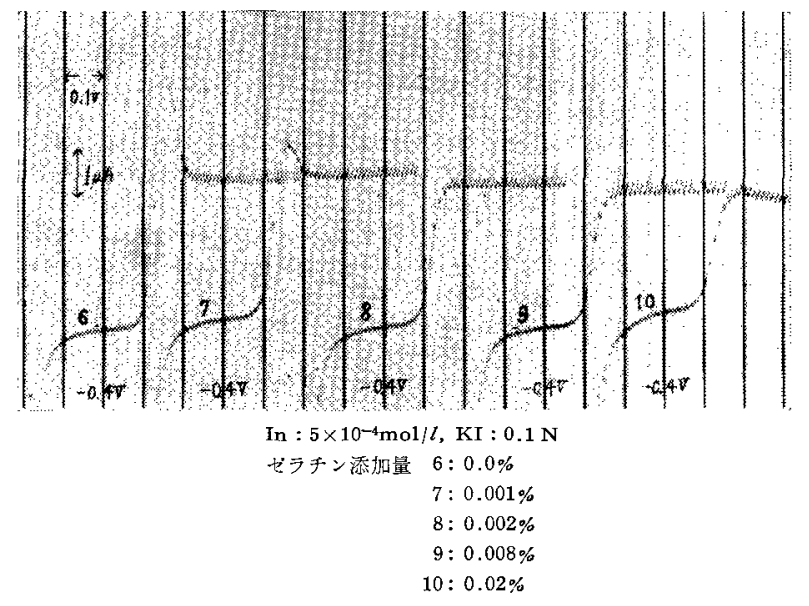

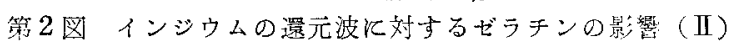

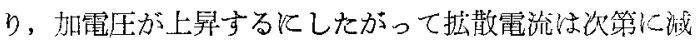
少して行く傾向が認められた.（岫線 10)

\section{4. 考察}

前項に述べたように極大抑制剤としてゼラチンを打 ると，極大波は消減し典型的なポーラログラフ没が得り， れる．このとき極大波の消堿要するゼラチンの限界尼 は,インジウムの濃度, 支持電解質の榩度などによって 異なるよろである，また試料溶液の酸性度にも左标され るようである。前項の実験に扔けるようにインジムの 濃度が $5 \times 10^{-4} \mathrm{~mol} / l$ 程度の場合には，ゼラチン濃㪂し 比較的少量でよいが， $5 \times 10^{-3} \mathrm{~mol} / \mathrm{l}$ 程度になるとゼうテ ン濃度を $0.015 \%$ 程度にしなければ極大波を完全に消湠 させ得ない。

またヨードカリ溶液が $0.1 \mathrm{~N}$ ，インジウム䟴度が 5 $10^{-4} \mathrm{~mol} / l$ の場合, ゼラチンが $0.002 \%$ 程度で霞大波わ゙ 抑制され，典型的なポーラログラフ波が得られるが， $0.02 \%$ 程度になると，還元波の傾斜はゆるやかになり， 半波電位の点を中心にして非対称となる。この二つの埸

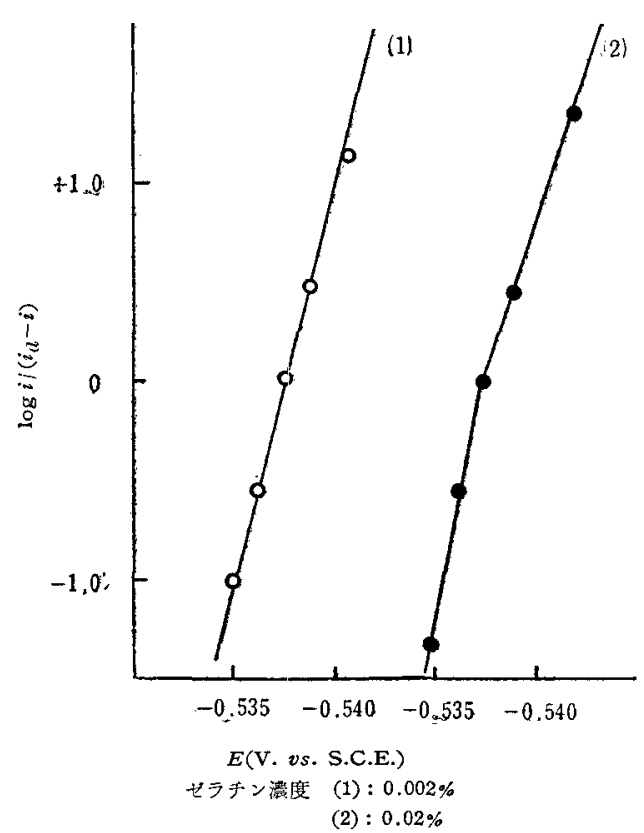

符 3 図 $E--\log \left\{i /\left(i_{d}-i\right)\right\}$ 図

合に扣けるポーラログラフ波から $E-\log \left\{i /\left(i_{d}-i\right)\right\}$ の関係を求めると第 3 図となり，前者に扔いては $E$

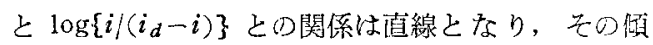
斜は約 $20 \mathrm{mV}$ である.したがって $R T / n F=0.02 \mathrm{~V}$ から $n \fallingdotseq 3$ が求めbれ， $\operatorname{In}^{3+}$ が金属インジウムに 罡元される可逆反沁であると考光られる。しかし後 者の場合怕 $E$ と $\log \left\{(i)\left(i_{d}-i\right)\right\}$ との関係㥀線 とならず, $\log \left\{i /\left(i_{d}-i\right)\right\}=0$ の点で折点をるつ二 つの面線となる。このことはヨードカリ溶液朴拉 ける $\mathrm{Zn}^{2+}$ の還元の場合炡名認められる(10).

これね多甾のゼラチンの影響によって滴下極の表田に 执いて，錯イオン形成源であるIーの濃度が一定上ふら ず非可迹反応になるためであるう。

インジウムがヨードイオンと錯イオンを形成し，无の

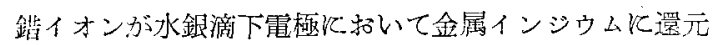
されアアマルガムを形成する応はつぎの反段階を絓虺す \%.

$$
\begin{aligned}
& \mathrm{InI}_{p^{(3-p)+} \rightleftharpoons \mathrm{In}^{3+}+p \mathrm{I}^{-}} \\
& \mathrm{In}^{3+}+3 \mathrm{e}+\mathrm{Hg} \rightleftharpoons \mathrm{In}(\mathrm{Hg})
\end{aligned}
$$

この場合ョードイオンの冁度変化による半波電位のずれ や次つ式で与光られる。

$$
\lrcorner E_{1 / 2}=-p \frac{R T}{n F} \log C_{\mathrm{I}^{-}}
$$

ここで $C_{\mathrm{I}}$ はヨードイオンの濃度をあらわす，第2 装 に示した結果から $E_{1 / 2}$ を $\log c_{I^{-}}$に対して点部すれば 第4圈となる。

挧に括いてヨードイオンの濃度が約 $0.5 \mathrm{~N}$ の辽で斯点 る有する二つの直線が得られ，0.5 N 以下では直線の傾 


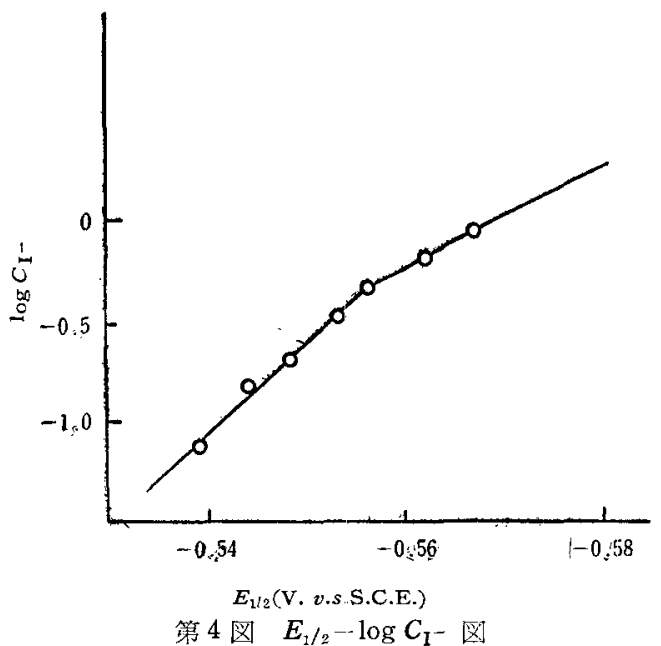

斜は約 $20 \mathrm{mV}$ となり, $0.5 \mathrm{~N}$ 以上では約 $40 \mathrm{mV}$ とな る、すなわち $C_{\mathrm{I}}<0.5$ のときは $p=1$ となり， $\mathrm{InI}^{2+} な$ る錯イオンが存在し， $C_{\mathrm{I}}>0.5$ のときに梳 $p=2$ となり $\mathrm{InI}_{2}{ }^{+}$なる錯イオンが存在すると考光られる。

\section{5. 総 括}

以上の結果を要約すると

1） $0.1 \mathrm{~N}, 1.0 \mathrm{~N}$ のヨードカリ澄液を基整液としたと きのインジウムとカド:ウムゆ還元波の半波電位はそれ ぞれ $-0.53_{\eta},-0.56_{2} \mathrm{~V}$ (vs.S.C.E.) 招よび $-0.62_{\imath},-$ $0.74_{1} \mathrm{~V}$ (vs.S.C.E.) である.したがって塭化力リ溶液を
基礎液としたときに重複波を示すインジウムとカドミウ ムはヨードカり溶液中では明瞭な分離波を示す。

2) インジウムはヨードカリ溶液中性いて $\operatorname{InI}^{2+}$ 打 よび $\operatorname{InI}_{2}+な る$ 錯イオンを形成して存在し，その電極反 応怡问逆反応であると考克られる。

3）インジウムの濃度が $5 \times 10^{-3} \mathrm{~mol} / l$ から $2 \times 10^{-4}$ $\mathrm{mol} / l$ の轮囲で，拡散電流上濃度が比例する．したがっ てインジムの還元波の波高を測定することによってイ ンジウムを定量することが可能である.

この研究在行うにあたってご愁篤なるご指導を赐わっ 攵恩沛京都大学理学部石橋雅義教授飞深く感謝する。

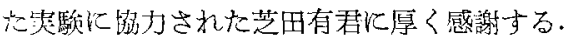

(昭 34-1-5 受理)

\section{文献}

(1) J. Heyrovsky: Chem. Listy, 19, 168 (1925)

(2) S. Takagi : J. Chem. Soc., 1929, 301

(3) J.J. Lingane : J. Am. Chem. Soc., 61, 2099 (1939)

(4) J.A. Schufle, M.F. Stubbs and R. Wilmann : J. Am. Chem. Soc., 73, 1013 (1951)

(5) D. Cozzi, S. Vivarell : Z. Elektrochem., 57, 408 (1953)

(6) H. Nakatani : $J$. of Science of the Hiroshima Univ. Series $A ., 19,183$ (1955)

(7) I.M. Kolthoff and J.J. Lingan: "Polarography, 1st Ed. Appendix : Half-Wave Potentials of Inorganic Substan.ces" p.11 (1941)

(8) 品川睦明：日化, 65, 319, 410 (1955)

(9) 守永㯬一：日化，75，627(1954)

(10) 松前鼎一: 未発表（昭和 33年 4 月 日本化学会第11年会に抹いて 撛演)

\title{
二酸化鉊 の結晶 形亡放電特性*
}

\section{Discharge Behaviours of Electrodeposited $\alpha$-and $\beta-\mathrm{PbO}_{2}$ Electrode}

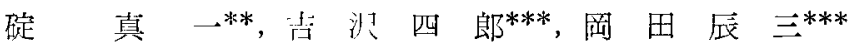 \\ Shinichi IKari Shiro Yoshizawa Shinzo OKada
}

\section{1. 緒言}

前報(1) そ扔いて鉛蓄奄池ペースト式陽極板活物質中の 二酸化鉛には $\operatorname{rhombic}(\alpha$ 型) 怙上び tetragonal $(\beta$ 型 $)$ の二種類の結晶形の異なるものがありそそれぞれの物質 が生成される条件ならびにて極板内怙和る存在の状 態について指摘した，本報では二酸化鉛の結晶形の相異 に基づく陽極板としての電池性能の差異について実験を 行った.

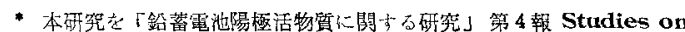
the Positive Material of Lead Storage Batteries Part 4) とする。本破究の一部は昭和 33 年 4 月電気化学協会講演会沅おい て発蓄した。

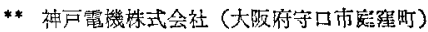

***京都大学工学部 (京都市左京区声旷本町)
な招，鉛蓄電池陽極板に関する従来の報告は，すべて $\alpha-\mathrm{PbO}_{2}$ 之 $\beta-\mathrm{PbO}_{2}$ を区别することなく論議されて招り， 鈔蓄雷池陽極活物質の研究としてはきわめて不十分であ ると思われる，ところで通常の製造条件のると作成さ れた極校では， $\alpha-\mathrm{PbO}_{2}$ あるいは $\beta-\mathrm{PbO}_{2}$ のいずれか一

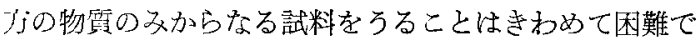
出る。一方極板について両者の確実な量的比率を知り得 たとしてもそれれぞれの物質は極板内での存在の場所拧 らび状態が異なるので，通常のペースト式極板を用いて 《ーむるいは $\beta-\mathrm{PbO}_{2}$ の電池特性を検討することは好まし くない，本実験では酸性招よびアルカり性浴から結晶形 の異なる $\mathrm{PbO}_{2}$ を白金板上飞電析した電極を用いてその

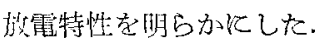

